\title{
Improvement of Quality of Care in Inflammatory Bowel Disease: the Role of Steroid Assessment Tool (SAT) - Results from a Tertiary Center Trial
}

\author{
Loredana GORAN', Lucian NEGREANU ${ }^{1}$
}

\begin{abstract}
Background and aims: Corticosteroids play an important role in the treatment of inflammatory bowel disease patients. They are used for induction of remission but due to their numerous side-effects they are avoided in the long term treatments. In order to improve medical care for the IBD patients guidelines were developed to avoid steroid excess and to promote regular monitoring of corticosteroid use. The aim of this study was to evaluate corticosteroid treatment using an online tool in a tertiary IBD centre from Romania. Methods: An online monitoring tool - SAT (Steroid Assessment Tool) was used to assess disease characteristics, corticosteroid use, corticosteroid excess as defined by international guidelines and the use of bone protection medication associated to steroid treatment. Two successive evaluations of patients treated in a tertiary IBD center were made, the first one in March 2019 on 44 patients and the second one 12 month later, in March 2020, on 84 patients. Data were statistically analyzed with SPSS $®$ software. Results: The results showed that in 2019 the rate of corticosteroid use was of 34\%, while in 2020 there was a decrease of corticosteroid use up to 25\%. Regarding steroid excess, in 2019 there were $20.4 \%$ of patients treated with steroids in excess, but we managed to reduce it to $5.95 \%$ in 2020, a decrease that was statistically significant. Bone protection medication was prescribed to only $6.6 \%$ of patients treated with corticosteroids in 2019, but a significant increase up to 95\% was obtained in 2020. Discussions: Two SAT evaluations of a tertiary IBD centre from Romania revealed that despite new therapeutic options, the rate of steroid use was higher than that reported in other international studies. The objective evaluation of steroid use determined a change in managing IBD patients, thus we succeeded to decrease significantly the rate of steroid excess and increase the use of calcium and vitamin D associated to corticotherapy. Conclusions: The use of an objective tool for monitoring corticosteroid use determined an improvement in managing IBD patients and thus of quality of care.
\end{abstract}

Keywords: IBD, steroid assessment tool, corticotherapy, steroid excess, quality of care.

\section{Rezumat}

Introducere și obiective: Corticosteroizii încă au un rol important în tratarea pacienților cu boli inflamatorii intestinale, în ciuda numeroaselor efecte adverse asociate utilizării acestora. Pentru a îmbunătăți serviciile medicale oferite pacienților cu boli inflamatorii intestinale, mai multe organizații internaționale au definit standarde de calitate ale îngrijirii acestor pacienți, între care evitarea utilizării corticosteroizilor în exces și monitorizarea periodică a utilizării

${ }^{1} 1^{\text {st }}$ Department of Internal Medicine and Gastroenterology, Emergency University Hospital, "Carol Davila" University of Medicine and Pharmacy, Bucharest, Romania

\section{Corresponding author:}

Loredana GORAN, $1^{\text {st }}$ Department of Internal Medicine and Gastroenterology, Emergency University Hospital, "Carol Davila" University of Medicine and Pharmacy, Bucharest, Romania.

E-mail: goran_loredana@yahoo.com 
corticoterapiei sunt recomandări principale. Obiectivul acestui studiu a fost acela de a evalua utilizarea corticoterapiei într-un centru terțiar de boli inflamatorii intestinale din România, cu ajutorul unei aplicații online. Metode: Am utilizat o aplicație online - SAT (Steroid Assessment Tool) pentru a evalua caracteristicele bolii, rata de utilizare a corticoterapiei, utilizarea în exces a acesteia așa cum este definită de către ghidurile internaționale de tratament și rata utilizării medicamentelor de protecție osoasă asociate corticoterapiei. Au fost efectuate două evaluări ale unui centru terțiar de boli inflamatorii intestinale, prima în martie 2019 pe 44 de pacienți, iar a doua a fost efectuată 12 luni mai târziu, în martie 2020, pe 84 de pacienți. Datele au fost analizate din punct de vedere statistic cu ajutorul programului SPSS®. Rezultate: Rezultatele au arătat că în anul 2019, rata utilizării corticoterapiei era de 34\%, pe când în anul 2020 s-a înregistrat o scădere a acesteia de până la 25\%. În ceea ce privește utilizarea corticosteroizilor în exces, în anul 2019, 20.4\% dintre pacienți erau tratați cu corticosteroizi în exces, dar am reușit să obținem o scădere a acesteia de până la 5.95\% în anul 2020, o scădere ce a atins semnificație statistică. Medicamentele pentru protecție osoasă asociate corticoterapiei au fost folosite în procent de $6.6 \%$ în anul 2019, dar o creștere semnificativă de până la 95\% s-a înregistrat în anul 2020. Discuții: Două evaluări succesive, cu ajutorul SAT, ale unui centru terțiar de boli inflamatorii intestinale din România au arătat că, în ciuda noilor opțiuni terapeutice, rata utilizării corticosteroizilor a fost mai mare decât cea raportată în alte studii internaționale. Evaluarea obiectivă a utilizării corticoterapiei a determinat o schimbare în tratamentul și monitorizarea pacienților cu boli inflamatorii intestinale, astfel că am reușit să scădem semnificativ utilizarea corticosteroizilor în exces și să crestem utilizarea medicamentelor de protectie osoasă asociate corticoterapiei. Concluzii: Utilizarea unui instrument de monitorizare obiectivă a corticoterapiei a determinat o îmbunătățire a managementului pacienților cu boli inflamatorii intestinale și astfel a calității îngrijirii oferite acestora.

Cuvinte cheie: boli inflamatorii intestinale, corticosteroizi, calitatea vieții, SAT, centre dedicate.

\section{BACKGROUND}

Inflammatory bowel diseases (IBD) are chronic diseases that affect approximately 2.5 million European citizens and 1 million Americans, most of them being young patients with a poor quality of life due to complications related to these diseases and their treatment ${ }^{1}$. Despite new treatments like immunomodulators and biologic therapies, corticosteroids still have an important role in induction of remission of IBD ${ }^{2}$.

Long term administration of corticosteroids is associated with numerous side-effects and a lack of efficiency in maintaining remission ${ }^{3,4}$ thus current international guidelines of treatment for IBD do not recommend the use of corticosteroids as a maintenance treatment ${ }^{5-7}$.

Quality of care in IBD brings out standards of care designed to improve medical services offered to IBD patients but the complexity of these diseases and their treatment slows down the definition of quality indicators, objective parameters for evaluation of quality of care. Many international organizations and groups of specialists dedicated to the study of IBD defined sets of quality indicators in IBD and most of them recommend to avoid excess use of corticosteroids and consider regular evaluation of corticosteroid use an indicator of quality of care ${ }^{8-11}$.
In order to improve quality of care in IBD centres we need objective tools that can be used to evaluate regularly quality of care indicators. The goal of our study was to reveal the value of a corticosteroid monitoring tool in daily practice of a tertiary IBD centre from Romania.

\section{METHODS}

\section{Definition of steroid excess}

Steroid excess is defined by international guidelines as the inability to reduce the doses of steroid below the equivalent of prednisolone $10 \mathrm{mg} /$ day or budesonide $3 \mathrm{mg} /$ day within 3 months of starting the steroid use without signs of recurrent active disease or a disease relapse within 3 months of stopping the treatment or more than one course of steroids per year ${ }^{12,13}$.

\section{Steroid Assessment Tool (SAT)}

AbbVie alongside with 15 gastroenterologist form the United Kingdom developed an online tool - SAT in order to monitor and evaluate the use of corticosteroids ${ }^{14}$. This tool allows to register patients diagnosed with IBD and contains 8 questions related to disease characteristics and treatment. Within the application it can be registered the diagnosis of the patient, the severity of the disease at the last evaluation, the anterior and 
current treatment and the use of corticosteroids in the last 12 months. If the patient received corticosteroids in the last year it can also be registered how many courses of steroids has the patients received, if bone-protection medication was prescribed, the longest duration of steroid use in months, if it was possible to reduce the dose of steroids below the equivalent of prednisolone $10 \mathrm{mg} /$ day (or budesonide below $3 \mathrm{mg} /$ day) within 3 months of starting the treatment without recurrent disease and if there was a relapse of the disease within 3 months of stopping steroids.

\section{Study design}

Data were collected using SAT between January 2019 and March 2020 and inclusion criteria were adult patients (older than 18 years) with an established diagnose of IBD according to international guidelines. We made two evaluations of a tertiary IBD centre from Romania using SAT, the first one in March 2019 when we had 44 patients with IBD and the second one was made one year later, in March 2020, when 84 patients with IBD were included. We used SPSS ${ }^{\circledR}$ software (v.21) ${ }^{15}$ to make the statistical analyze and the descriptive graphics. The Chi-squared test was used to determine if there is any statistically significant difference between the expected and the observed frequencies of one ore more units of a contingency table with a level of statistical significance of $\mathrm{p}=0.05$.

\section{RESULTS}

The first evaluation of our centre using SAT was made in March 2019 on 44 IBD patients and a second evaluation took place 12 months later, in March 2020 on 84 IBD patients, thus our study included a total of 128 IBD patients.

Regarding disease type there were 84 patients (64\%) with Crohn's disease (CD) and 46 patients (36\%) with ulcerative colitis (UC) with a mean age of 36.11 $( \pm 11.81)$ in the CD group and of $45.33( \pm 13.09)$ in the UC group. 88 patients were of male gender and the rest of 40 patients were females. The results of severity evaluation at the last visit showed us that most of the patients (81 patients, 63\%) had mild disease, 40 patients (31\%) had moderate disease and 7 patients (5.4\%) were evaluated as having severe disease.

Assessment of medication revealed that $90 \%$ of $\mathrm{pa}^{-}$ tients included in the study (115 patients) have been treated or are being treated with 5-amino-salycilates (5-
ASA) while $10 \%$ have never been treated with 5-ASA. The rate of current use of 5-ASA is $42 \%$, while the rest of the patients had 5-ASA in their previous treatments. The percentage of thiopurines use in our study is a low one with only $11.7 \%$ of patients being treated with this class of drugs, while the use of TNFa inhibitors is higher, $66 \%$ of the patients included being treated with this class of drugs before or during the study. The use of anti-integrin therapy and anti IL23/IL12 antibodies is even lower than that of thiopurines with a percent of use of 3.9\% for anti-integrin therapy and of $1.5 \%$ for anti IL23/IL12 antibodies.

Evaluation of the use of corticosteroids with SAT revealed that in 2019, 15 patients (34\%) of the 44 patients included in the study received treatment with corticosteroids in that last 12 months while in 2020 there were 21 patients (25\%) treated with corticosteroids of the total of 84 patients included (Figure 1).

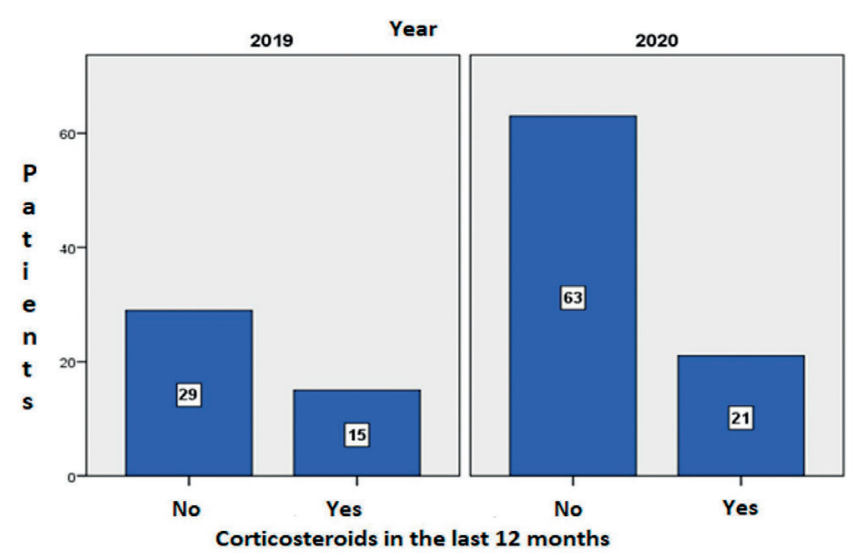

Figure 1. The use of corticosteroids administered in the last 12 months to IBD patients in 2019 and 2020

Even though the percent of patients that were treated with corticosteroids in 2020 (25\%) is lower than one year before (34\% in 2019), the reduction was not statistically significant $\left(\mathrm{X}^{2}=1.18, \mathrm{p}=0.27\right)$.

The evaluation of corticosteroid use depending on disease type showed that $37 \%$ of UC patients and $23 \%$ of $\mathrm{CD}$ patients received corticotherapy in the last 12 months before the SAT evaluation.

The evaluation of corticosteroid excess using SAT revealed that in 2019 there was a 20.4\% (9 patients out of 44 included) corticosteroid excess and the rate dropped to $5.95 \%$ (5 patients out of 84 included) in 2020 after measures were implemented (Figure 2). 


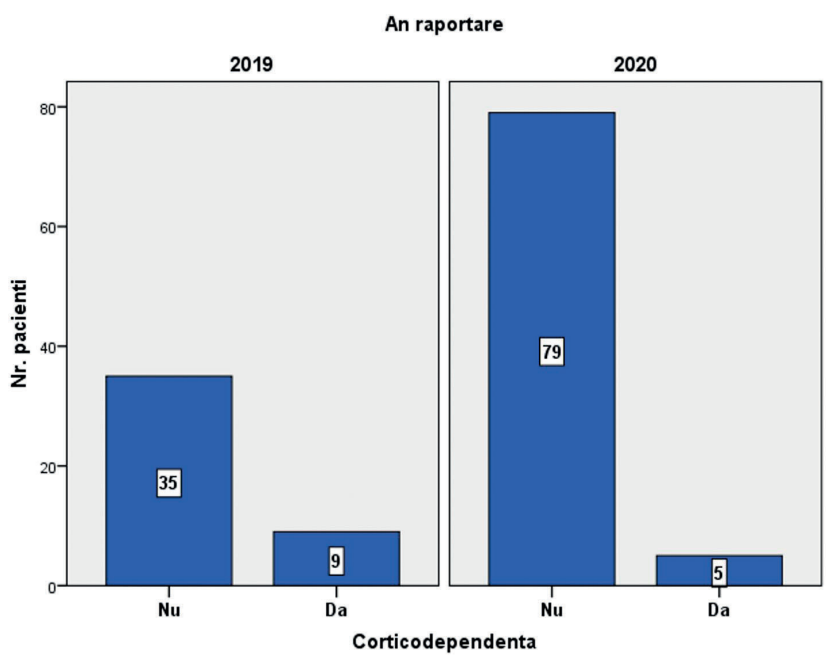

Figure 2. Distribution of corticosteroid excess between 2019-2020

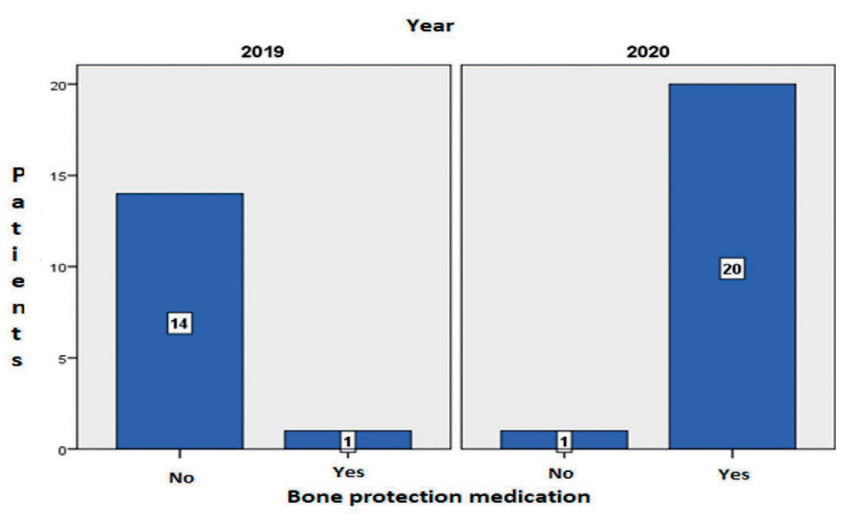

Figure 3. Distribution of bone protection medication of patients treated with corticosteroids during 2019-2020

We have a decrease of the percentage of steroid excess from $20.4 \%$ in 2019 to $5.95 \%$ in 2020, a reduction that reached a poor but statistically significant differentiation $\left(\mathrm{X}^{2}=6.23, \mathrm{p}=0.01\right.$, Cramer's $\left.=0.22\right)$.

We have analyzed the steroid excess depending on disease type and observed that there was a total of $6 \mathrm{pa}^{-}$ tients (7.3\%) with $\mathrm{CD}$ and steroid excess and 8 patients $(17.3 \%)$ with UC and steroid excess. Even though the percentage of patients with steroid excess is higher in the UC group that in the CD group, we did not find a statistically significant differentiation between disease type and steroid excess $(\mathrm{p}=0.08)$.

Also, a moderate correlation between steroid excess and disease severity was found $\left(\mathrm{X}^{2}=53.20, \mathrm{p}=0.001\right.$, Cramer's $\mathrm{V}=0.64)$. There is a higher probability for patients with moderate $\left(\mathrm{X}^{2}=4.90, \mathrm{p}=0.02\right.$, Cramer's
$\mathrm{V}=0.19)$ and severe $\left(\mathrm{X}^{2}=42.50, \mathrm{p}=0.001\right.$, Cramer's $\mathrm{V}=0.57)$ disease to be corticodependent.

In 2019 there were 15 patients treated with corticosteroids but we noticed using SAT that only one patient (6.6\%) had also a prescription of bone protection medication. This finding made us take action and in 2020, $95 \%$ of patients treated with steroids ( 20 out of $21 \mathrm{pa}-$ tients) had also a prescription of bone protection medication, an increase that reached statistically significance $\left(\mathrm{X}^{2}=28.24, \mathrm{p}<0.001\right.$, Cramer's $\left.\mathrm{V}=0.88\right)$ (Figure 3).

\section{DISCUSSIONS}

We assessed a tertiary IBD centre from Romania using SAT at an interval of 12 months in order to evaluate corticosteroid use in these patients. The first evaluation was made in March 2019 on 44 patients and the second one in March 2020 on 84 patients, so a total of 128 patients were included in our study. We had more patients diagnosed with CD (64\%) than patients with UC (36\%), the majority of them being of male gender $(68 \%)$ and with a mean age of 39 years.

The evaluation of treatment revealed that there is a high percentage (90\%) of 5-ASA administration to IBD patients and these percent includes patients that were treated with 5-ASA before the evaluation (57\%) or are still under treatment (42\%). Even though in the last years a decrease of 5-ASA prescriptions was registered $^{16}$, other studies confirm a high use of 5-ASA in IBD patients ${ }^{17}$. Regarding the use of TNF $\alpha$ inhibitors we noticed that we have a high rate of prescriptions, $63.4 \%$ of CD patients and $43 \%$ of UC patients using this class of medication currently comparative to other studies were the reported rate for $\mathrm{TNF} \alpha$ inhibitors was of $23.9 \%{ }^{18}$. In the same time, we have a low rate of thiopurines use of only $11 \%$ relative to $62.6 \%$ of patients from a study made in the United Kingdom ${ }^{17}$, but a slightly higher rate of anti-integrine therapy.

Assessment of disease severity showed that majority of patients were considered to have mild $(63 \%)$ or moderate (31\%) forms of disease at the last evaluation, while $5.4 \%$ of patients were considered to have severe disease. We consider that the high number of mild and moderate cases is due to the fact that the patients were strictly monitored and therapeutic management was duly adapted in order to avoid complications. Maybe the high rate of TNF $\alpha$ inhibitors use is related to the high number of mild and moderate forms of disease, but a significantly statistic correlation was not obtained between the two results. 
We first evaluated the use of corticosteroids with SAT in our IBD centre in March 2019 when 44 patients were assessed and the rate of corticosteroid use was $34 \%$. The next SAT evaluation was made 12 months later on 84 patients from the same IBD centre and rate of corticosteroid use decreased to $25 \%$, a decrease with no statistical significance $(p=0.27)$. Compared to other international studies out rate of corticosteroid use in 2019 was higher, respectively in a study from the United Kingdom that included a significant higher number of patients it was $30 \%{ }^{17}$. Also, in Asia the rate of corticosteroid use in IBD patients was $26.3 \%{ }^{19}$, smaller than the one we obtained in 2019, but higher than the one in 2020.

Evaluation of corticosteroid use depending on disease type revealed that $23 \%$ of $\mathrm{CD}$ patients and $37 \%$ of UC patients were treated with corticosteroids in the last 12 months before SAT evaluation. A higher rate of corticosteroids use in UC patients compared to CD patients was confirmed in other studies too ${ }^{20}$.

Corticosteroid excess according to guidelines definitions was evaluated with SAT to be $20,4 \%$ in 2019 (9 patients out of 44 patients) and a statistically significant decrease ( $p=0.01$ ) was registered in 2020 when the steroid excess rate was of $6 \%$ ( 5 patients out of 84 patients). The steroid excess rate in 2019 was similar to the one reported by a study made in Kent where the steroid excess was evaluated to be $21 \%{ }^{21}$, but higher than the one reported in another study from United Kingdom ${ }^{17}$. Also, compared to other studies where only a small and statistically insignificant decrease of steroid excess was obtained $^{18}$, we managed to obtain a significant reduction of corticosteroid excess.

Patients with moderate and severe disease courses have a higher probability to be treated with corticosteroids in excess as we obtained a moderate but statistically significant correlation between steroid excess and disease severity ( $\mathrm{p}=0.001)$, correlation that is confirmed in larger studies as well ${ }^{17}$.

The first SAT evaluation of IBD patients made in March 2019 revealed that only 6,6\% of patients treat- ed with corticosteroids received also a prescription of bone protection medication, a smaller percentage than that obtained in an Italian study where $38 \%$ of patients received calcium and vitamin $\mathrm{D}$ associated to steroid treatment ${ }^{22}$. After the first evaluation made in 2019, we managed to take action regarding bone protection medication associated to corticosteroid treatment and in March 2020, 95\% of IBD patients treated with steroids received calcium and vitamin $\mathrm{D}$ too, an increase that was statistically significant $(\mathrm{p}<0.001)$. Similar results, with an increase of bone protection medication between two evaluations, were registered in a study from Kent ${ }^{21}$.

Assessment of corticosteroid use made in 2019 with SAT revealed a high rate of corticosteroid use and a higher steroid excess than the rates reported in international studies. These results brought a change in managing IBD patients, particularly regarding corticosteroid use and bone protection medication. The second evaluation made in 2020 pointed out that we succeeded to reduce significantly steroid excess and increase the rate of bone protection medication prescriptions as recommended by international guidelines of treatment.

\section{CONCLUSIONS}

We made an objective assessment of an IBD centre emphasizing on corticosteroid use, an indicator for quality of care. We consider SAT a useful and easy to use monitoring tool for corticosteroid use as we managed to make significant changes after using it in order to improve quality of care for IBD patients.

Compliance with ethics requirements: The authors declare no conflict of interest regarding this article. The authors declare that all the procedures and experiments of this study respect the ethical standards in the Helsinki Declaration of 1975, as revised in 2008(5), as well as the national law. Informed consent was obtained from all the patients included in the study. 


\section{References}

1. Kaplan GG. The global burden of IBD: From 2015 to 2025. Nature Reviews Gastroenterology and Hepatology. 2015.

2. Neurath MF. Current and emerging therapeutic targets for IBD. Nature Reviews Gastroenterology and Hepatology. 2017.

3. Lewis JD, Scott FI, Brensinger CM, Roy JA, Osterman MT, Mamtani $R$, et al. Increased mortality rates with prolonged corticosteroid therapy when compared with antitumor necrosis factor-a-directed therapy for inflammatory bowel disease. Am J Gastroenterol. 2018.

4. Steinhart AH, Ewe K, Griffiths AM, Modigliani R, Thomsen 00 . Corticosteroids for maintenance of remission in Crohn's disease. Cochrane Database Syst Rev. 2003.

5. Torres J, Bonovas S, Doherty G, Kucharzik T, Gisbert JP, Raine T, et al. ECCO guidelines on therapeutics in Crohn's disease: Medical treatment. Journal of Crohn's and Colitis. 2020

6. Lamb CA, Kennedy NA, Raine T, Hendy PA, Smith PJ, Limdi JK, et al. British Society of Gastroenterology consensus guidelines on the management of inflammatory bowel disease in adults. Gut. 2019.

7. Lichtenstein GR, Loftus E V., Isaacs KL, Regueiro MD, Gerson LB, Sands BE. ACG Clinical Guideline: Management of Crohn's Disease in Adults. American Journal of Gastroenterology. 2018

8. Fiorino G, Lytras T, Younge L, Fidalgo C, Coenen S, Chaparro M, et al. Quality of care standards in inflammatory bowel diseases: a European Crohn's and Colitis Organisation (ECCO) position paper. J Crohn's Colitis. 2020.

9. Melmed GY, Siegel CA, Spiegel BM, Allen JI, Cima R, Colombel JF, et al. Quality indicators for inflammatory bowel disease: Development of process and outcome measures. Inflammatory Bowel Diseases. 2013.

10. Wong DJ, Kantschuster RM, Matini L, Simadibrata DM, Lepetyukh M, Wilson J, et al. SU1938 PATIENT REPORTED OUTCOMES: THE ICHOM STANDARD SET FOR IBD IN REAL LIFE PRACTICE HELPS QUANTIFY DEFICITS IN CURRENT CARE. Gastroenterology. 2020.

11. Nguyen GC, Boland K, Waqqas A, Bressler B, Jones JL, Weizman A $\mathrm{V}$, et al. Modi fi ed Delphi Process for the Development of Choosing Wisely for In fl ammatory Bowel Disease. 2017;23(6):858-65.
12. Torres J, Bonovas S, Doherty G, Kucharzik T, Gisbert JP, Raine T, et al. ECCO Guidelines on Therapeutics in Crohn's Disease: Medical Treatment. J Crohns Colitis. 2020.

13. Harbord M, Eliakim R, Bettenworth D, Karmiris K, Katsanos $K$, Kopylov U, et al. Third European evidence-based consensus on diagnosis and management of ulcerative colitis. Part 2: Current management. J Crohn's Colitis. 2017.

14. https://www.steroidassessmenttool.com/.

15. SPSS [Internet]. Available from: https://www.ibm.com/analytics/ spss-statistics-software

16. Chhaya V, Saxena S, Cecil E, Subramanian V, Curcin V, Majeed A, et al. Steroid dependency and trends in prescribing for inflammatory bowel disease - a 20-year national population-based study. Aliment Pharmacol Ther. 2016.

17. Selinger CP, Parkes GC, Bassi A, Fogden E, Hayee B, Limdi JK, et al. A multi-centre audit of excess steroid use in 1176 patients with inflammatory bowel disease. Aliment Pharmacol Ther. 2017;46(10):964-73.

18. Selinger CP, Parkes GC, Bassi A, Limdi JK, Ludlow H, Patel P, et al. Assessment of steroid use as a key performance indicator in inflammatory bowel disease-analysis of data from $2385 \mathrm{UK}$ patients. Aliment Pharmacol Ther. 2019.

19. Kim DH, Park DI, Kobayashi T, Ahuja V, Jang BI, Cao Q, et al. P691 Corticosteroids usage in patients with inflammatory bowel disease: Results of a multi-national audit in Asia. J Crohn's Colitis. 2020.

20. Okayasu M, Ogata H, Yoshiyama Y. Use of corticosteroids for remission induction therapy in patients with new-onset ulcerative colitis in real-world settings. J Mark Access Heal Policy. 2019.

21. Scott G, Roads N, Lewis W. P280 Reducing the overprescribing of oral corticosteroids in IBD using a steroid assessment tool. J Crohn's Colitis. 2018;12(supplement_1):S242-S242.

22. Fasci-Spurio F, Meucci G, Papi C, Saibeni S. The use of oral corticosteroids in inflammatory bowel diseases in Italy: An IG-IBD survey. Dig Liver Dis [Internet]. 2017;49(10):1092-7. Available from: http://dx.doi.org/10.1016/j.dld.2017.07.005. 